\title{
1960 "REVOLUTION" IN TURKEY AND THE BRITISH POLICY TOWARDS TURKEY
}

\author{
CIHAT GÖKTEPE
}

\begin{abstract}
There was a military coup in Turkey on May 27, 1960. This paper examines the main causes of the coup and the effect of Anglo-Turkish Relations. The subject is analysed within seven headings: 1) The Political Parties and The Army; 2) Inter-party relations; 3 ) The incidents that led to the coup; 4) The coup and its aftermath; 5) Britain's relations with Turkey before the military coup; 6) The British attitude towards the coup; 7) The British attitude towards the trial and the execution of the members of the fallen regime.
\end{abstract}

\section{KEY WORDS:}

Turkish Politics; Turkish British Relations; Military in Turkey 1960 Coup in Turkey; Inönü; Menderes. 


\section{Political Parties and the Army in Turkey}

The Turkish Republic was founded on October 29, 1923 after three-year struggle against the occupier countries. In that year the People's Party was renamed as the Republican People's Party (RPP), which continued to rule Turkey until 1950 in a single party political system. After the Second World War, the Turkish political system evolued towards a multiparty system, affected by a number of internal and external factors. Four RPP members of parliament, C. Bayar, F. Köprülü, R. Koraltan and A. Menderes, either resigned or were expelled from their party in 1946. They formed a new political party called the "Democrat Party" (DP), on January $7,1946 .{ }^{1}$ It was surprisingly successful within a short period and won a large majority in the general elections of May 14 1950, obtaining 416 out of available 487 seats in the National Assembly. They managed to defeat the RPP despite the continued respect for Atatürk, its founder, and the charisma of İnönü, Atatürk's successor. At the end of the elections the RPP transferred power to DP in an orderly manner. ${ }^{2}$ The DP's first chairman Celal Bayar was elected as the third President of Turkey by the Grand National Assembly of Turkey on May 22, 1950. One of the founders of the DP, Adnan Menderes, replaced Bayar as the chairman of the party simultaneously. His first government obtained the vote of confidence from the Assembly on June 2, 1950. The transfer of the governmental power from the RPP to the DP became known as the "White Revolution" (Ak Devrim) for the DP supporters. ${ }^{3}$

DP's ideology and programme advocated more freedom for the people, a liberal economic policy with more support for private industry and less for the state sector, together with less restriction on the practice of the Muslim religion. ${ }^{4}$ These liberal policies were generally welcomed by the people at large. The Democrats were seen as the populist, rural party and the Republicans as elitist and urban,

\footnotetext{
${ }^{1}$ Mehmet Ali Birand, Can Dündar, Bülent Çaplı, Demirkırat; Bir Demokrasinin Doğusu, İstanbul, Milliyet, 1995, p. 26.

${ }^{2}$ Walter F. Weiker, The Turkish Revolution, 1960-1961: Aspects of Military Politics, Washigton D.C., The Brookings Institution, 1963, p. 7.

${ }^{3}$ Feroz, Ahmad, The Turkish Experiment in Democracy, 1950-1975, London, C. Hurst, 1977, p. 38.

${ }^{4}$ Weiker, The Turkish Revolution, p. 8.
} 
which was supported generally by the intelligentsia. ${ }^{5}$ Most of the intellectuals, however, supported DP when it was founded in 1946, because of its commitment to greater freedom.

The military was another significant factor in Turkish politics, which enjoyed close working relations with the government during the period of single party rule (1923-1950). The officers respected Atatürk and his comrade İnönü, the president and prime minister respectively. The change of the government to the DP did not immediately lead to tension with the military, largely because the RPP was willing to respect the result of the elections and to hand over power. Menderes then went on to win two further general elections against the opposition party, the RPP, in 1954 and 1957, thus the period between 1950 and 1960 came to known as the DP or Menderes era in Turkey.

In the meantime, the Marshall Plan was proclaimed in June 1947 and the US and later Turkey signed a protocol for latter's participation in the Plan. Turkey received a substantial amount of foreign economic and military assistance from the US according to the 1948 agreement. $^{6}$ This amount was extended, particularly during the Menderes administration. Of this aid, almost 70 percent were spent on the agrarian modernisation through mechanisation with investments in tractors and harvesters. ${ }^{7}$ These imports were to lead to further heavy expenditure on spare parts in later years. The government also used Marshall aid to build roads, bridges and water projects for both the urban and the rural areas. ${ }^{8}$

These developments led to a considerable social and economic transformation of the country. Migration increased from rural to urban areas. Peasants progressively received more money, as Turkey

\footnotetext{
${ }^{5}$ Ahmad, The Turkish Experiment, p. 44.

${ }^{6}$ During the period of $1948-1952$, Turkey received $\$ 351.7$ million American aid. Duygu Sezer, "Türkiye'nin Ekonomik łlişkileri", in Mehmet Gönlübol et. al, Olaylarla Türk Dıs Politikası, 1919-1990, Ankara, Siyasal Kitabevi, 1993, p. 448.

${ }^{7}$ George Harris, Troubled Alliance, Turkish-American Problems in Historical Perspective, 1945-1970, Washington D.C., American Enterprise Institute for Public Policy Research, 1972, p. 71.

${ }^{8}$ Ahmad, The Turkish Experiment, p. 134.
} 
became an exporter of grain. This situation, described as the "golden years" of the Menderes era, lasted until 1955.

During the first period of DP government, it was sensitive to the religious feeling of the public. In 1950 the DP abolished the 1928 law prohibiting the use of the Arabic form of call to prayer. The entire country immediately dropped the Turkish translation that the earlier law had required. The building of mosques was increased. The RPP had agreed in 1949 to allow religious instruction in schools should parents requested it for their children in writing. The Democrats altered this to provide religious instruction for all Muslim children unless their parents requested in writing that the children were not to receive it. The RPP had authorised the creation of a faculty of divinity within Ankara University, and the training of imams by private individuals in order to meet the well-taken objection that if no new religious leaders were trained, either Islam would die out altogether or fall into the hands of the uneducated and the covert. The Democrats followed this, vastly expanding the number of institutions for training imams. This silent struggle for scarce resources seems highly symbolic of the greater struggle between the forces of secularism and Islam in Turkey. ${ }^{9}$ The DP Government seemed pro-religious, but at the same time they announced what was popularly known as the "Atatürk Law", on July 25, 1951. The new law was designed both to protect Atatürk reforms, statues and monuments and at the same time to prevent the defamation of the DP government. The fact that the President and ex-chairman of the DP, Celal Bayar, was a close friend of Atatürk, also played a part in this decision. In short the DP was nominally pro-Islamist, but in reality a secular pro-reformist party.

The DP government also attempted some reforms in the administration and the military that tended to support the RPP. There was rivairy between the social groups, consisting of rural people and traders on the one side that supported the DP, and intellectuals, military and bureaucrats on the other, who voted mainly for the RPP. This situation became especially true after 1955 .

Once in office, however, the DP's election promise to reduce the number of military officers did not last long. Prime Minister Adnan Menderes and the other Democrat leaders, however, soon

\footnotetext{
${ }^{9}$ Weiker, The Turkish Revolution, p. 9.
} 
developed a thinly veiled contempt for the officer corps, possibly because their vote did not bulk large in the party's political calculations. Under the DP, the military usually played little part in the ruling councils. Although at this time the armed forces were being revitalised as a result of the American aid programme that provided modern weapons and training for the officers, who thus gained more respect internationally, they were frustrated because of their inability to influence their generals, or through them the government at home. The Democrats also allowed their salaries to lag far behind the rapidly rising cost of living. From the emotionally charged recitals of complaints by officers in their strained circumstances, it was clear that the DP permitted the status and prestige of the military profession to sink lower at home than it had at any time since the founding of the Republic. These developments only reinforced the officer corps in their identification with the opposition party and with the civilian educated elite who also opposed the government for different reasons. Certainly there was a growing disenchantment of the military with the DP.

The officers, having been brought up to view themselves as the naturally appointed guardians of Atatürk reforms were especially sensitive to the claims of opposition parties that the DP was not sufficiently firm in defending Kemalist principles. Some were upset with the Democrats' concession in the matter of religion. The officers were even more disturbed at what they perceived as the lack of Turkey's development as a modern nation-state under the DP regime. In its quest for votes, the Party had concentrated on measures to please the common man. ${ }^{10}$ Particularly after foreign exchange reserves inherited from the RPP government were exhausted and the weather cycle turned unfavourable, these crowd-pleasing measures led to a runaway inflation, an acute balance of payments crisis and great shortages of imported consumer goods.

The broadly felt impact of this economic dislocation generated further sympathy among the officers for the RPP and gave more credit to the allegations that the DP had no consistent development plan and that the government was wasting Turkey's resources in politically motivated endeavours that had little, if any, economic justification. In

\footnotetext{
${ }^{10}$ George Harris, "The Causes of the 1960 Revolution in Turkey", Middle East Journal (MEJ), Vol 24, Autumn 1970.
} 
this situation the officer corps felt particularly outraged by widely believed rumours of rampant corruption among civilian politicians. This led first to salon plotting among some of the younger and middle ranking officers, who as early as 1954 began to talk of "righting the wrongs" of the system. From grievances against the top army command this dissatisfaction gradually broadened to include the workings of the political order, too. ${ }^{11}$

The British Ambassador to Ankara, Sir Bernard Burrows sent a confidential despatch to London, dated on July 3, 1960, which accurately analysed the situation. He pointed out that the middle-and junior-ranking officers had long disliked the DP government and many of them identified with the educated classes and sympathised with the opposition. In addition, their own conditions of pay and service were very poor. ${ }^{12}$ The senior officers were no doubt aware of these feelings among their juniors. They had themselves great respect for İnönü, personally, rather than for his party. They strongly disapproved of the government's use of the army to repress student demonstrations. They wished "to keep the army free of politics and to retain its close bonds with the people"13.

It would, however, be a mistake to generalise too much. There were mixed attitudes from the military. Many officers were devoted to İnönü as the comrade of Atatürk, though not always to the Republican Party as such; others resented the use of the Army for political purposes; yet others, had deeper and more radical views on Turkey's political future. They believed that all politicians were bad and that a sweeping change in the system of government was necessary, at least for some time to come, not merely to get Turkey out of its political crises. In order to complete the work Atatürk had began, they believed that a new, and in some cases unpopular, long term reforms were needed, which only a newly elected government would feel to be strong enough to undertake. These diverse elements came together

\footnotetext{
${ }^{11}$ Ibid., pp. 438-454

${ }^{12}$ Foreign Office Papers, London, Public Record Office (henceforth referred to as "FO"), 371/153O34, RK 1015/33, Bernard Burrows to FO, Ankara, 3 June 1960.

13FO-371/153O34, RK 1015/33, Burrows to Ankara, 3 June 1960.
} 
within political conspiracy and carried out the coup in a remarkably efficient and successful manner. ${ }^{14}$

The DP's government gradually lost the support of the intellectuals, whose desertion became virtually complete between 1955 and 1960 . The intellectuals criticised the government's direct involvement in the universities, sanctions against the press, and the DP's use of radio for its propaganda rather than for the public interest. Intellectuals started a passive resistance together with the students demonstrations against the government. Thus the RPP, intellectuals and the press formed a group against the government. To meet this threat, the DP members voted in the Assembly on April 18, 1960 to set up a "Parliamentary Commission", staffed entirely by DP members, to investigate the political activities of the oppositioni. 15 The point of no return was probably reached with the granting to the Commission of practically unlimited powers to forbid all political activity, even right to surpress the reporting in the press of parliamentary debates with regard to the Commission's activities. ${ }^{16}$ The Commission was immediately condemned as unconstitutional and anti-democratic by the opposition groups. They protested on the streets of Ankara,İstanbul and İzmir, and significantly the army did not put them down. The intervention came about because the military finally realised that "passive resistance" to the government's order to repress demonstrations was not enough to solve the crisis in which Turkey found itself and that they must instead take "positive action" to change the situation. ${ }^{17}$

The formation of the group, which planned and carried out the 1960 coup, seems to have started in 1955 when two young officers, Dündar Seyhan and Faruk Güventürk, began to form a cell of radically-minded officers. They called themselves the Revolutionary Committee, or just the Committee and expanded their activities throughout 1957 and 1958. The Ankara group formed at the end of

${ }^{14} \mathrm{FO}-371 / 16 \mathrm{O} 212$, RK 1011/1, Burrows to FO (The Earl of Home), Ankara, 6 January 1960.

${ }^{15}$ Cem Eroğul, Demokrat Parti Tarihi ve Ideolojisi, Ankara, Imge, 1990, p. 155.

${ }^{16} \mathrm{FO} 371 / 16 \mathrm{O} 212$, RK 1011/1, Burrows to FO (The Earl of Home), Ankara, 6 January 1960 .

${ }^{17}$ Ibid. 
1956 by Talat Aydemir, Osman Köksal, Sezai Okan and Adnan Celikoğlu, and İstanbul committee decided to merge their networks in 1958. ${ }^{18}$ Two things were crucial to the success of their planned takeover. One was the posting of their members to command positions, which were essential for the take-over of power, and the other was to find a senior officer to head their movement in order to gain the support of the rest of the armed forces. Eventually, they were successful on both counts. ${ }^{19} 1959$ and the spring of 1960 was busy times for the Committee and by May 1960 they were in a position to strike. After a few failed attempts, they found the senior officer they needed as a figure head; General Cemal Gürsel, a former commanderin-chief of the land forces, who had been placed on a permanent leave on May 3, 1960 because of his written a memorandum to the Minister of Defence that expressed the discontent of the military towards government policies. ${ }^{20} \mathrm{He}$ was acting as the representative of the discontented military in demanding the resignation of the government.

The Defence Minister, Ethem Menderes, brought the letter to Prime Minister. When he saw the memorandum, he decided to resign. However, the President Celal Bayar refused his resignation and sent a message of support. Then, Menderes changed his mind when he was informed of the President's attitude. ${ }^{21}$ It seemed that he hoped that he and his government still had the capacity to repress the demonstrations and to solve the internal problems of the country. He thought general public support was behind him. One crucial point though, the President was not informed about the memorandum neither Ethem nor by Adnan Menderes.

The memorandum was very clear and the last warning to the government before the military coup. The government did not seem to grasp its significance. The Chief of General Staff, General Rüştü Erdelhun, was loyal to the government and was known to oppose any

${ }^{18}$ William Hale, Turkish Politics and the Military, London and New York, Routledge, 1994, p. 100.

${ }^{19}$ Erik J. Zürcher, Turkey, A Modern History, London, Tauris, 1994, pp. 253-254.

${ }^{20}$ Stanford J. Shaw \& Ezel Kural Shaw, History of the Ottoman Empire and Modern Turkey, Vol. II, London, Cambridge University Pres, 1977, p. 414.

${ }^{21}$ Birand/Dündar/Çaplı, Demirkırat, p. 168. 
intervention against Menderes. Moreover, twenty generals visited the Prime Minister and confirmed that they would obey the government, thus the government decided to rely on the hierarchical discipline of the Turkish Army. They did not expect any conspiracy from the middle-ranking and junior officers against the government.

General Gürsel, an easy-going and fatherly figure, was wellknown and well-liked throughout the armed forces. He agreed to become head of the Committee but he was not involved in the details of its organisation. Essentially, the coup originated with a group of middle-ranking and junior officers, who brought their commanders into their preparations only at a relatively late stage. As mentioned by George Harris: "It had been [in] essence [a] colonels' coup, with merely a facade of senior officers recruited by their juniors, to take advantage of the strong hierarchical sense of the Turkish military profession". ${ }^{22}$ When the coup took place on May 27, 1960, General Gürsel was brought from İzmir to Ankara by an airforce plane as the head of the Revolutionary Committee.

\section{Inter-Party Relations}

During the DP decade (1950-1960), there were two main political parties in Turkish politics. The DP was in government while the RPP was in opposition. In the general elections on May 14, 1950, the DP received 53.3 percent of the general vote and 420 seats in the Grand National Assembly of Turkey (GNAT) while the RPP received 39.9 percent of the vote and 63 seats. ${ }^{23}$ Just after the 1950 elections and the transfer of power from the RPP to the DP, there was a shortlived political honeymoon. ${ }^{24}$ For a few years the regime was as liberal as any Turkey had known. The DP's first leader Celal Bayar agreed that there were no ideological differences and both parties were committed to the programme of developing a modern and prosperous Turkey. The Democrats pledged to make Turkey "little America"

${ }^{22}$ Harris, The Causes of the 1960 Revolution, pp. 438-454.

${ }^{23}$ Kemal Karpat, "Political Developments in Turkey, 1950-1970", Middle Eastern Studies, Vol. 8, 1972, pp. 348-375; and Shaw/Shaw, History of the Ottoman, pp. 406-407.

${ }^{24}$ Roderic H. Davison, Turkey, A Short History, Huntigton, Eothen, 1988, p. 153. 
within a generation, with a millionaire in every province. The Republicans had followed a similar programme. The difference between the parties was not about the goals, but over the methods. ${ }^{25}$

However, the DP was not as homogenous as it appeared to be. Though its central leadership came directly from the RPP, its grassroot support came from people who first engaged in politics only after the opposition was set up in $1946 .{ }^{26}$ These people had suffered severely under Republican one-party rule and hated the RPP blindly. They shaped provincial DP branches independently of the party's central organization and wished to achieve power in order to exact revenge on their former oppressors. They criticised Menderes for being a continuation of the RPP and for not offering the country a different policy and programme. Menderes heard such complaints repeatedly in local party congresses and was more annoyed by this conflict within his own party than by the official opposition. His way of appeasing dissidents was to take severe measures against the RPP such as censorship of the press and radio for the RPP, despite their earlier promise that they would not "question the past". 27

The DP soon launched an open attack on the opposition. Considerable amount of property of the RPP was confiscated on the grounds that it had been illegally acquired through the misuse of public funds during the single party era. Their local party headquarters were closed. A new press law imposed heavy penalties for publishing inaccurate information that might endanger Turkey's stability. ${ }^{28}$

The 1954 election was still free and fair. The DP's majority of the popular vote increased to 58 percent and it received 503 seats in the Assembly while the RPP garnered only 35 percent and 31 seats. The electoral system used in Turkey in the 1950s, was inherited from the first Ottoman electoral regulations of 1876. Each of the 64 (subsequently 67) provinces served as a constituency electing one member if its population was under 55.000, and an additional member

${ }^{25}$ Feroz Ahmad, The Making of Modern Turkey, London, Routledge, 1993, p. 109.

26Ibid., p. 111.

${ }^{27}$ Ahmad, The Turkish Experiement, p. 67.

${ }^{28}$ Davison, Turkey, p. 153. 
for every 40.000 inhabitants. The number of parliamentary seats thus had to be adjusted upwards in every election to cope with the rise in the population. As a result the assembly seats increased from 487 in 1950 to 602 in 1957 . With a few exceptions, all citizens over twentyone were given the franchise.

Moreover, the simple majority system was used, which allowed the front-runner in each constituency to obtain all the seats regardless of the percentage of votes it received. This procedure can be illustrated using, for example, the Konya province during the 1957 elections. Konya returned 21 deputies for the Assembly. The share of the votes of the four parties competing in Konya was as follows; RPP $40.9 \%$, DP $44.3 \%$, NP (Nation Party) $10.5 \%$, and FP (Freedom Party) $4.4 \%$. Notwithstanding the narrowness of its lead, the DP all 21 seats because of the simple majority system. It is hard to believe any other electoral system would have produced the same result, unless the elections were carefully rigged. The fact that this effect was repeated in the majority of constituencies in all three elections during the 1950s gave the Democrats massive parliamentary majorities despite its slender advantage of the popular vote. For example, in the 1950 election the DP received $53.3 \%$ of the votes, but gained $83.7 \%$ seats in the Assembly. In the 1954 election, the figures were $56.6 \%$ and $91.6 \%$. On the other hand, numbers for the RPP's were $34.2 \%$ and $5.6 \%$ in 1950 and $39.9 \%$ and $14.2 \%$ in 1954, respectively. ${ }^{29}$ Therefore, the parliamentary representation was not an accurate reflection of public tendencies. The election system was designed during the single party period by the RPP, but created significant advantages for the DP during the 1950s.

The increased majority, coupled with the worsening economic situation, seemed to drive the Democrats towards a more authoritarian rule even though there were criticisms from within the party. The "liberal group", which favoured free enterprise and political freedom, opposed the pressure of state authority over the economy, as well as their aim to control political activity. Nineteen DP members either resigned or were expelled from the party because of their opposition.

${ }^{29}$ William Hale, "The Role of the Electoral System in Turkish Politics", International Journal of Middle East Studies,Vol. 11, 1980, pp. 401-417. 
They formed a new political party in December 1955, called the Freedom Party (Hürrriyet Partisi). ${ }^{30}$

The increasingly heavy-handed methods of the DP also led the opposition parties towards collaboration. In August 1957, representatives from the opposition parties started to hold meetings. At the same time, in September 1957, Fuat Köprülü (one of the founders of the DP) resigned from the party and joined the opposition. ${ }^{31}$ These initial steps towards co-operation alarmed the Democrats and they decided to hold the 1958 elections a year earlier than planned. To prevent the opposition from joining forces, they enacted a new electoral law forbidding electoral alliances between parties.

Thus, the general election of September 27, 1957 was held in a tense climate and number of incidents occurred during the election campaign. Despite all the efforts of the opposition, the DP lost only 9.3 percent, once again emerging as the strongest party with close to 48 percent of the vote, while the RPP received about 41 percent. The remainder went to the Republican Nation Party $(7 \%)$ and to the Freedom Party (4\%). The DP's seats in the parliament decreased from 505 to 424 and the RPP increased its seats from 31 to $178 .{ }^{32}$ After the election, the opposition parties argued that the new government was not legitimate. They urged the government to resign because its total vote was under 50 percent. The result of the election only increased the political chaos. The RPP, thirsty for triumph and an increased representation in the Assembly, stepped up the fierce criticism and frequency of its assault on Menderes and his associates. The government responded by continued acts of repression, and the violence mounted in and out of the parliament.

The foreign policy of the DP was also heavily criticised by the opposition. Although the RPP had mainly followed a similar policy during the post-war period towards the West, they condemned the DP government as "more Westernised than the West". It meant that

${ }^{30}$ Cem Eroğul, "The Establishment of Multiparty Rule:1945-71" in I. C. Schik and E. A. Tonak (eds.), Turkey In Transition, New Perspectives, Oxford, Oxford University Press, 1987, pp. 101-143.

${ }^{31}$ Ibid., p. 115.

${ }^{32}$ Karpat, Political Developments In Turkey, pp. 349-375. 
Turkish foreign policy became depended on West, particularly upon US interest in the Middle East. As a matter of fact, the Turkish policymakers increasingly saw themselves during the 1950s as the representative of the West within Turkey's immediate neighbourhood. This was exaggerated by the opposition.

In the Cold War atmosphere, Turkey was looking for an alliance against her expansionist neighbour the Soviet Union. Thus, on August 1, 1950, Turkey formally applied for admission to the North Atlantic Treaty Organisation (NATO). At the NATO council meeting in September, Norway and Denmark strongly opposed the entry of both Turkey and Greece. The Europeans were not keen to extend their commitment beyond the North Atlantic region. Britain wished Turkey to stay out of NATO, because she wanted to see Turkey becoming the cornerstone of an alliance in the Middle East. As a result Turkish application was rejected. ${ }^{33}$ However, the Korean War was an opportunity for Turkey to gain access to NATO. The DP government decided to send a brigade of 4500 troops under the UN framework to Korea on July 25,1950 . The opposition was not informed about this significant decision by the government. By the end of the war, there were 1200 casualties among the Turkish forces. ${ }^{34}$

This heavy price accelerated Western acceptance of Turkey's military co-operation. The Pentagon had begun to appreciate the strategic importance of Turkey as well as the military augmentation she could make to the alliance. Finally, Britain, too, announced its support for Turkey's admission to NATO, and in September 1951 the Scandinavian countries also withdrew their objections. Finally Turkey, together with Greece, became a full member of NATO February 28, 1952. After that, Turkey's foreign and defence policies were planned according to mutual defence principles of the Atlantic Alliance.

Meanwhile, Turkey also signed bilateral agreements with the US. Most of these agreements were not ratified by the parliament, and were only approved by the foreign ministry or military institutions.

\footnotetext{
${ }^{33}$ Ahmad, The Turkish Experiment, p. 391.

${ }^{34}$ Selim Deringil, "Turkish Foreign Policy since Atatürk" in Clement H. Dodd (ed.), Turkish Foreign Policy, London, Eothen, 1992, pp. 1-8.
} 
There were 54 bilateral agreements all together; three of them were signed before 1950, 31 were signed during the DP period (19501960), and the rest (20) after 1960. According to these agreements, the US Government obtained the right to establish American military bases in Turkey. Accordingly, the opposition condemned the government's action as a violation of Turkey's sovereignty and national security. 35

In the meantime, the Turkish, Greek and Yugoslav foreign ministers on the instigation of the US government, signed a Friendship and Co-operation Treaty in Ankara in February 1953.36 On August 9, 1954 it was transformed into an alliance and a military pact, namely, the Balkan Defence Pact. ${ }^{37}$ Although the Pact opened up the possibility of support from the US against the USSR and its satellites, it was short-lived, especially after Stalin's death in 1953 as Western-oriented Turkey, Greece and socialist Yugoslavia could not always agree on the direction from which the mutual threat was supposed to come. Finally Khruschev's visit to Belgrade in May 1955 determined the fate of the Pact. Tito changed his policy towards military alliances and became a leader of the non-aligned movement with Nehru and Nasser. Same year also saw the Turkish foreign minister, F. R. Zorlu, supporting the idea of a defensive pact and the continuation of alliance systems with the West at the Bandung Conference of non-aligned countries on 18-24 April.

Greco-Turkish relations also deteriorated after 1955 because of the Cyprus dispute. As a result, the Balkan Pact effectively died in 1955, though it survived officially until 1960 when it was dissolved by its members because of increasingly divergent aims of its members.

Turkey also became a formative member of the Baghdad Pact together with Iraq on February 24, 1955, which was a heavy blow for Arab unity and to Turkey's relations with the Arab countries. Britain officially joined the Baghdad Pact on April 4, 1955, followed by Pakistan on September 23. Iran joined on November 3, 1955, giving

\footnotetext{
${ }^{35}$ Gönlübol, Olaylarla Türk Dış Politikası, pp. 235-236.

36Ibid., p. 238.

${ }^{37}$ Hüseyin Bağcı, Demokrat Parti Dönemi Dış Politikası, Ankara, Imge, 1990 , p. 57.
} 
the Pact its final form. Finally it was renamed CENTO on August 21, 1959 after Iraq withdrew from the Pact as a result of a coup on July 14,1958 . The new Pact left out Iraq but brought in the US as an observer. Both CENTO and its precursor established defensive arrangement against the USSR, forming "the Northem Tier." ${ }^{38}$ Thus Turkey played the leading role in the realisation of Western policy in the Middle East, directed toward "containing" the USSR with military alliances. ${ }^{39}$

Criticism of Turkish foreign policy from the internal opposition, when it came, was centred largely on matters of detail and on ways the government carried out its policy, not on the underlying strategy. For example, F. R. Atay, a well-known RPP journalist, expressed his anxiety that Turkey appeared to be taking a "provocative" stance in championing opposition to the USSR in the Middle East. İnönü also recognised that there were difficulties in reconciling Turkey's regional policies in the Balkans and the Middle East towards the Soviet Union and Greece. Speaking in the name of his party, he warned the DP leadership to pay close attention to reconciling the obligations of Turkey's different security groupings, including the Baghdad Pact. However at the outset ,the DP's domestic critics did not yet seem prepared, as they would become by the end of the following year, to blame the government for alienating some Arab states especially Egypt and Syria by seeking other Arab members for the Baghdad Pact; Iraq, Jordan, and Lebanon. ${ }^{40}$

On March 5, 1959, the DP government approved a bilateral treaty with the US, which was strongly criticised by the opposition for its vague wording. It stated that the US government would support Turkey against any direct or indirect involvement from outside. The opposition argued that the limits of the indirect involvement should be clarified by the government as they feared that the US forces might be employed to keep the DP in the government even if it loses power through elections. Despite the opposition's objections, the treaty was approved by the Assembly by the DP's majority on May 9, 1960.

${ }^{38}$ Nurhan Ince, Problems and Politics in Turkish Policy, 1960-1966, Unpublished PhD Dissertation, University of Kentucky, 1974, p. 30.

${ }^{39}$ Eroğul, Demokrat Parti, p. 101.

${ }^{40}$ Harris, Troubled Alliance, p. 63. 
During the 1950, Turkey not only became the forward shield of the West, but also a champion of the Cold War. The DP leaders continually expressed deep suspicion of the Soviets. They were not receptive to the new policy of the post-Stalinist Soviet leaders who had denounced Stalin's expansionist policies and urged better relationship with Turkey. That the Soviets had been shifting to a position of a peaceful process in East-West relations was ignored by the DP leadership who continued to rely on US and NATO support $v i s$ - $d$-vis the USSR, despite the fact that these countries were by now engaged in détente with the Soviets. ${ }^{41}$

The British Ambassador Sir Bernard Burrows in analysing Turkey's situation in 1960 commented; "It is one of the many paradoxes of this eventful year how the Democrat Party Government could internally embark on so dangerous and ill judged a course, while in its foreign policy it showed such steadfastness as a member of the Western alliance". 42 The Ambassador also explained the new trend in the Turkish-Soviet's relations;

There were signs towards the end that even in foreign policy the strain was beginning to tell. M. Menderes was heard to mention rather enviously on more than one occasion how much easier it was for a totalitarian system like Russia to carry out measures of economic development in a short time. His agreement to exchange visits with M. Khrushchev may be regarded not only as a prudent withdrawal from Turkey's previously extreme anti-Russian position, but also as a hope of distraction from the internal crisis. ${ }^{43}$

His analysis was mainly correct, but it should be mentioned that the negative attitude of the US towards Turkey's economic aid demands and the general policy of détente between the blocks also affected the Turkish-Sovict relations. Another factor was that the Turkish politicians now realised their error of blindly following NATO and Western policy. They thought they needed to improve Turkey's relations with her northern neighbour too. The Soviets also offered a significant amount of aid and credit to Turkey. According to the exchange visit agreement between the two governments,

${ }^{41}$ Gönlübol, Olaylarla Türk Dıs Politikası, p. 312.

${ }^{42} \mathrm{FO} 371 / 160212$, RK $1011 / 1$, Burrows to FO (The Earl of Home), Ankara, 6 January 1961.

${ }^{43}$ Ibid. 
Menderes was scheduled to visit Moscow in July 1960, but was not able do so in the event because of the coup on May 27, 1960.

\section{The Incidents That Led to the Coup}

There were various events accelerating the tension within the country, which led to the coup. Although some had began earlier, they converged mainly in the spring of 1960 .

The political tension steadily increased after the 1957 election, as the inter-party relations deteriorated following the election. Then, Menderes' aeroplane crashed near Gatwick Airport on the journey to the London Conference on February 17, 1959. Menderes escaped from the crash but twelve passengers died. The Gatwick air crash might have an opportunity for both sides to improve their relations. Menderes was welcomed back home by huge crowds, and the opposition leader İnönü, too, met him at Ankara station. They shook hands and İnönü asked Menderes to accept his good wishes. It was the last time the two leaders shook hands. ${ }^{44}$ They would never meet again in friendly circumstances before the coup.

The road leading to the extinction of the DP began on April 19, 1959, when İnönü, the 75-year-old RPP leader, as well as other party members and journalists, started what was called the "Grand Offensive", a tour of country with a party train. ${ }^{45}$ The train's first stop was Uşak in western Turkey, and the group was met by a demonstration organised by the government supporters, one of whom was a 16-year-old youth who threw a stone that injured İnönü in the head. ${ }^{46}$ This aroused anger throughout the country and was exploited by the RPP. It also affected the military circles due to their respect for İnönü, a former general and veteran of the Independence War. And, on May 3,1959, Turkish newspapers were issued with blank columns for the first time. In return, the government issued a press decree aiming to control and censor any statements by the opposition.

${ }^{44}$ Eroğul, Demokrat Parti, p. 146.

${ }^{45}$ Eroğul, The Establishment of Multiparty Rule, p. 117.

${ }^{46} \mathrm{FO}-371 / 153032$, RK 1015/10, Burrows to FO (Selweyn Lloyd), Ankara, 22 April 1960. 
At the end of the Aegean tour, İnönü went from İzmir to Istanbul by air. His car was attacked by a crowd at Topkapi on the way from the airport to the city. Fortunately, Inönü was saved by the prompt interference of an army unit, which had previously been ordered not to intervene. The RPP supporters publicised the event of the Topkapı incidents and they alleged that it was a planned attack with the aim of killing İnönü but making it appear as if this was accidental. 47

In the spring of 1960, these kinds of incident increased whenever the opposition leader and other RPP members who represented him launched tours throughout Anatolia. For example, İnönü visited Konya in February 1960 and the police used tear-gas and truncheons to disperse the Republicans who turned out to meet him. ${ }^{48}$ On April 3, 1960, he was to visit the town of Kayseri in central Anatolia. The government decided to prevent this visit. Accordingly, the governor of Kayseri stopped İnönü's train and ordered him to abandon his plan, but İnönü took no notice and eventually the train took him on his way. However, the next day the governor called on armed forces to obstruct him from going on to Yeşilhisar, which was situated half way to Niğde. The soldiers did not obey the governor's order because of their respect for İnönü. Then, a colonel and two majors resigned in protest against being ordered to deprive him of his constitutional right to take a trip where he pleased. They were promptly arrested.

The Kayseri incident had twin importance: it both confirmed the extent to which, as Hale pointed out, Menderes was prepared to go to chain down the opposition, and also indicated that he might not be able to count on the support of the army, if he needed it. ${ }^{49}$ The Ambassador Burrows was of the same opinion in his despatch: "Its immediate effect was a serious blow to the Government's credit. In view of M. İnönü's great prestige among the bulk of the Turkish armed forces, it is still difficult to understand what was in the Government's mind in attempting to use units of the army against his

${ }^{47}$ Hale, Turkish Politics, p. 105.

${ }^{48}$ Lewis, Modern Turkey, p. 152.

${ }^{49}$ Hale, Turkish Politics, p. 105. 
person". ${ }^{50}$ This was, infact, a turning point. The relations between the army and the opposition against the government was closer than ever before.

Following the Kayseri incident, İnönü met with a group of former generals and admirals in his house on April 17, 1960 and told them it was up to them to protect the ideals of Turkish progress. ${ }^{51}$ This led the DP to announce that it would investigate whether the RPP was secretly inciting the armed forces to disobey the law and order. The Investigation Commission was established on April 18. All of the 15 members of the Commission were chosen from DP rank. It was to investigate political activities, the press, and meetings, which were banned immediately by the Commission. ${ }^{52}$ Nine days later, a further law gave the Investigation Committee draconian right of inspection and arrest. İnönü protested; "If you continue on this road, even I will not be able to save you". ${ }^{53}$ Earlier on, he was reported to say that "When the conditions compel it, revolution is the legitimate right of nations". ${ }^{54}$ Afterwards İnönü was punished for his speeches by being expelled from the Assembly for the next twelve sessions. Thus the Assembly lost its function to solve problems within the parliament.

As the political tension increased, university students throughout the country began to protest the government policies. During demonstrations by the İstanbul University students on 28 April 1960, the army and police suppressed the students. Two students were killed, and many were injured. Due to censorship of the press, details of the events were not made public. However, rumours spread quickly to the affect that sixty or more students had been killed. As the protest increased, the government declared martial law with a curfew in İstanbul and Ankara on April 28, 1960.55 On April 29 , there were crowds demonstrating in Ankara in a meeting

${ }^{50}$ FO-371/153032, RK1015/10, Burrows to FO (Selweyn Lloyd), Ankara, 22 April 1960.

${ }^{51}$ Hale, Turkish Politics, p. 106.

52FO-371/153032, RK 1015/10, Burrows to FO (Selweyn Lloyd), Ankara, 22 April 1960.

${ }^{53}$ Weiker, The Turkish Revolution, p. 15.

${ }^{54} \mathrm{Hale}$, Turkish Politic, p. 106.

55FO-371/153032, RK 1015/11, Burrows to FO, Ankara, 29 April 1960. 
organised by the students of the Political Science Faculty. The demonstrators called for Menderes' resignation. ${ }^{56}$

A NATO Ministers' council was scheduled to meet in İstanbul on May 2-4, 1960. However, Menderes cancelled his address to the meeting in order to stay in Ankara and remain in touch with developments. ${ }^{57}$ This clearly showed the seriousness of the situation to the foreign ministers of the NATO countries. Another important event occurred on $5^{\text {th }}$ of May in Ankara. Menderes was passing through Kizılay Square where a demonstration was being held. When he stopped his car and stepped out, he was manhandled by the strients, and managed to get into a journalist's car with difficulty, which had also, been accidentally trapped in the crowd. ${ }^{58}$ After his return to his office and meeting with the President, President Bayar gave an order to the Interior Minister Namık Gedik to open fire on the demonstrators. The security officers however did not fire. But this order was significant as it showed how Bayar had increased his influence over Menderes.

The last significant event before the coup occurred during the visit of the Indian Prime Minister Nehru to Ankara on 20-22 May. On May 21, about 1000 officers and cadets from the Army War College staged an orderly march to the presidential mansion in the suburb of Çankaya in protest for the arbitrary arrest of several officers. The event was regarded as an attempt to intimidate of the government.

Although there was substantial pressure on Menderes from all quarters to resign, he did not yield. Until about the beginning of April, political speculation centred on the question of whether the government intended to hold premature elections in the spring or the autumn. Legally, they did not need to be held until the middle of the following year. Members of the government and their supporters went a long way, however, short of actually announcing a date, to suggest that elections would be held before the summer. Tours by ministers to all parts of the country were characterised by blatant electioneering speeches that included the promised economic development and the preparation of new electoral registers.

56Eroğul, Demokrat Parti, p. 157.

${ }^{57}$ Weiker, The Turkish Revolution, p. 18.

${ }^{58}$ Birand/Dündar/Çapl,, Demirkırat, p. 172. 
The Prime Minister was himself favourable to holding-early elections. Unfortunately, however, he was unable to carry with him a sufficient majority of his party followers, including the President, who exercised a good deal of independent influence in party matters. The opponents of the early election might have been motivated by general uncertainty as to the result, but more likely it was for more personal considerations. At the time, members of parliament were drawing their salaries in advance for the whole four-year term for which they were elected. Accordingly if the Assembly was dissolved before the end of its term, they were, theoretically, obliged to repay the appropriate proportion of what they had drawn. ${ }^{59}$

Moreover, in some cases, while members might have been fairly sure of the election of their party, they might have had personal doubts owing to local rivalries, in terms of their selection as DP candidates. The Kayseri incident, too, had caused the government to revise sharply its estimate of easy electoral success. Finally, a newly obtained grant of $\$ 50$ million from Germany may have made the Government feel that they could more comfortably scrape through the rest of the year without a new economic crisis.

British ambassador Burrows analysed the political situation in Turkey with considerable insight. Consequently, the British Foreign Office was well informed and kept abreast of the rapidly changing and complex situation. He pointed out that, many outside observers thought that an election was likely to result in further victory of the democrats. However, the Government could not take the risk of going to the country either because they might loose or because an election would give rise to disorder which the army would be unwilling to suppress for the benefit of the Democrat Party. 60

Another factor was that while he was touring on the Aegean region, a huge enthusiastic crowd of almost 200 thousands met him in İzmir and showed their sympathy and support, which influenced the

${ }^{59}$ FO-371/153032, RK.1015/10, Burrows to FO (Selweyn Lloyd), Ankara, 22 April 1960.

${ }^{60}$ FO-371/160212, RK.1011/1, Burrows to FO (The Earl of Home), Ankara, 6 January 1961. 
Prime Minister's decision to stay on. ${ }^{61}$ Then he went to Eskişehir on 25 May and made a speech during a public meeting. He emphasised that they would abolish the investigation commission and declare an early election date. The crowd did not hear his words because the wire of the loudspeakers had been cut off. While he was still in Eskişehir, his secretary woke him up at 4 am on May 27, 1960 with the news of the military coup. ${ }^{62}$

\section{The Coup and Its Aftermath}

The coup took place during the night of May 27, 1960 with more or less simultaneous action in İstanbul and Ankara. In İstanbul, the operation went smoothly and quickly meeting with no resistance. The martial law commander, also first army commander, was said to have given a dinner party attended by military and civil supporters of the DP. These were promptly arrested at the end of the party.

The Third Armoured Brigade seems to have been the main component of the striking force with individual officers from the staff college in İstanbul also playing an important part. Tanks and troops were first observed moving into the city at about 2.30 a.m. Half an hour later they were in position and in control of the Vilayet (Governor's Place). Seizure of the central post office, the police headquarters, the railway stations, airport and radio station quickly followed. The leading members of the former regime were taken into custody. After some confusion, due to an inability to contact Ankara, İstanbul Radio broadcast the first announcements that the armed forces had taken control at 4.15 a.m. ${ }^{63}$

The operation in Ankara, on the other hand, began later than İstanbul and met with surprises. It has since been revealed that the margin between success and failure was narrower than it had first appeared. The garrison commanders of the Armoured Training Centre and the horsed cavalry (43rd Regiment) similarly refused to join the coup. The support of the troops under their command had, however, already been assured. The main striking force was the cadets of the

${ }^{61} 1_{\text {Birand/Dündar/Çapl, Demirkırat, p. } 135 .}$

62Ibid., p. 180.

${ }^{63}$ FO-371/153034, RK 1015/33(A), Burrows to FO, Ankara, 3 June 1960. 
War College, who, together with a large number of individual officers, formed the spearhead of the operation. Further supporting elements were reserve officers (i.e. conscript officers) and a number of infantry, largely trainees. ${ }^{64}$

The three most important individuals in the planning and execution of the operation in Ankara were the Logistic Commander of the Land Forces, the Chief of Training Staff on the General Staff and the Commandant of the War College. The cadets of the War College were instructed during the evening and issued with arms and ammunition. At about 3.30 a.m., a small number of senior officers, including the Chief of the General Staff, the acting Land Forces Commander and Martial Law Commander were arrested. A detachment consisting of tanks and trainee soldiers led by officers and cadets left immediately afterwards for the Presidential Palace to arrest Celal Bayar. Although the sympathies of the Presidential Guard Regiment, were uncertain this potentially delicate operation was carried out without bloodshed, largely by means of bluff. From then on matters proceeded smoothly. One detachment of cadets left at 3.45 a.m. to protect İnönü's house and others encountered little more than token resistance from gendarme and police in securing strategic points, such as the Prime Ministry, the Post Office and Radio Station. When the success of the operation was assured, the news of the overthrow of the government was broadcast by colonel Alparslan Türkeş over Ankara Radio in the following statement;

Honourable Fellow Countrymen: Owing to the crisis into which our democracy has fallen, and owing to sad incidents and in order to prevent fratricide, the Turkish armed forces have taken over the administration of the country.

Our armed forces have taken this initiative for the purpose of extricating the parties from irreconcilable situation which they have fallen and for the purpose of having just and free elections, to be held as soon as possible under the supervision and arbitration of an above party and impartial administration.

Our initiative is not directed against any person or class. Our administration will not resort any aggressive act against personalities, nor will it allow others to do so. All fellow countrymen, irrespective

${ }^{64}$ Ibid. 
of the parties to which they may belong, will be treated in accordance with the principles of law.

For the elimination of all our hardships and for the safety of our national existence, it is imperative that it should be remembered that all our fellow countrymen belong to the same nation and race, above all party considerations, and that therefore they should threat one another with respect and understanding without bearing any grudge.

All personalities of the Cabinet are requested to take with the Turkish armed forces. Their personal safety is guaranteed by law.

We are addressing ourselves to our allies, friends, neighbours and the entire world: Our aim is to remain completely loyal to the United Nations Charter and to the principle of "peace at home peace in the world" set by the great Atatürk. We are loyal to all our alliances and undertakings. We believe in NATO and CENTO and we are faithful to them. We repeat: Our ideal is "peace at home, peace in the world". 65

When Menderes and his companions heard the news in Eskişehir, they decided to go towards Kütahya. However, one of the air colonels, Muhsin Batur, was ordered to intercept Menderes and take him to Ankara. When the group arrived in Kütahya, Colonel Batur followed their convoy, arrested Menderes, and brought him to Ankara by air. The president, prime minister, and four generals were arrested together with 400 Democrat deputies and other supporters. They were then confined to Yassiada a barren islet near İstanbul.

The Commanders in İzmir and Erzurum had previously signified support for the movement. The remaining elements of the armed forces immediately declared their support. Martial law and a curfew were immediately imposed throughout the country. The coup was accepted throughout the country with only one or two very minor incidents of opposition being reported.

A notable feature had been the determination of the army to associate civilian and predominantly intellectual elements with the coup from the start. One consequence of this was that after the coup, when there was a move to draft a new constitution, several constitutional lawyers from İstanbul and Ankara Universities were summoned. This drafting of an entirely new constitution meant the

${ }^{65}$ Weiker, The Turkish Revolution, pp. 20-21. 
legitimisation of the movement. What had begun as a coup transformed into a "revolution" through the participation of the intellectuals in the drafting of the new constitution.

On May 27, the Constitutional Commission was instructed to start work immediately to reform the Constitution, and thus immediately form a civilian government. The Commission was headed by Professor Siddik Sami Onar who was the Rector of the University of İstanbul. Parallel with this, however, the military Committee of National Union continued to exist and was stated to be superior to the government, with General Gürsel providing the link between the two. ${ }^{66}$

Then, General Gürsel and 37 officers representing all branches of the armed forces (although predominantly from the army, with only three from the airforce, and two from the navy), organised themselves into the Milli Birlik Komitesi (National Unity Committee - NUC). It was largely composed of middle ranking officers. Their ranks were as follows: five generals, seven colonels, five lieutenant colonels, thirteen majors and eight captains. The overwhelming majority of NUC members were between 35 and 46 years of age. ${ }^{67}$

The NUC was a coalition of dissimilar factions in the armed forces, all hungry for power. The junta was large and unwieldy, because so many different secret groups claimed representation. The NUC assumed legal power to govern the country under a provisional law, enacted on June 12,1960. This document enabled the NUC to exercise sovereignty on behalf of the Turkish nation until an assembly had been elected under a new constitution. The legislative power of the junta was through the Cabinet commissioned by the Head of State who was also chairman of the NUC. The Committee could dismiss the ministers but only the Head of State could appoint them. Only the judiciary functioned independently of the junta and executive power remained in the hands of the civilian Council of Ministers, albeit

${ }^{66} \mathrm{FO}-371 / 153034$. RK. 1015/33, Burrows to FO, Ankara, 3 June 1960.

${ }^{67} \mathrm{Kemal} \mathrm{H}$. Karpat, "The Military and Politics in Turkey 1960-64; A SocioCultural Analysis of a Revolution", American Historical Review, Vol. 75, 1970, pp. 1654-1683; FO-371/153035,RK 1015/39, Burrows to Southern Department, 17 June 1960. 
under the scruting of the junta. ${ }^{68}$ The "Cabinet of Technocrats", as it came to be known, consisted of 18 members (three officers and 15 civilians) was a purely executive organ, appointed and controlled by the NUC. Thus, all important policy decisions were made by the NUC itself. 69

There were two major groups in the NUC. One group, which included General Gürsel and the other generals, referred as moderates, wished to restore power to the civilians within a short time. They supported the Onar Commission's proposals for a liberal and democratic Turkey. The second group was described as the radicals, and consisted predominantly of junior officers, with Colonel Türkeş emerging as a prominent figure. They wanted the junta to retain a powerful position so as to carry out a more thorough restructuring than that envisaged by the professors. They even talked of creating a "new culture" and a populist political system without parties. They were especially against the NUC's close relationship with or support of the Inönü's party, the RPP.

From May 27, for the next six months, the two groups in the NUC engaged in a power struggle. Finally, on November 13, the moderates carried out a coup and purged 14 NUC members with radical inclinations. They were all expelled under the canopy of "advisers" to Turkish embassies around the world. The first round of conflict was thus resolved. ${ }^{70}$

The new constitution was approved by the public through the referendum of July 9, 1961. After the referendum approved the Constitution, affairs moved steadily toward the election of October 15 , and the end of the formal existence of the NUC. The National Assembly of Turkey re-convened in Ankara in October 1961. General Gürsel was elected Turkey's fourth President by the Assembly on October 27, and the new civilian coalition government was formed by İnönü, the leader of the RPP, in October 1961.71

\footnotetext{
${ }^{68}$ Ahmad, The Making of Modern Turkey, pp. 126-127.

${ }^{69}$ Zürcher, Turkey, p. 254.

${ }^{70}$ Semih Vaner, "The Army" in Schick/Tonak, Turkey in Transition, pp. 236-265.

${ }^{71}$ Weiker, The Turkish Revolution, pp. 23-24.
} 


\section{Anglo-Turkish Relations Before the Coup}

The Anglo-Turkish relations since the establishment of the Turkish Republic had undergone significant changes. There were a number of issues in Anglo-Turkish relations before 1959, which continued to affect their relations in the period 1959-1965.

\section{Strategic and Defence Issues}

During the 1920s, Britain strongly opposed to the new Turkish National Government in Ankara during the period of the Liberation War (1919-1922) and did not recognise the new Turkish administration until the Lausanne Peace Treaty that was signed after intensive negotiations on July 24, 1923. After Lausanne, Turkey was preoccupied with domestic affairs and was determined to cure her backwardness by means of rapid orientation towards Western values. There were however number of unsettled points leftover from the Lausanne Treaty. The Mosul dispute which concerned the British mandate administration in Iraq was one of the more important problems that occupied the energy of the new Republic.

The agreement about Mosul was finally signed at the end of long negotiations in Ankara on June 5,1926 by the British, Turkish and Iraqi Governments. Turkey accepted the League of Nations' decision on Mosul, namely it ceded Mosul to Iraq, which was then under British mandate. ${ }^{72}$ The following visit of the British Mediterranean fleet to Turkey in October 1929 reflected the end of the Anglo-Turkish conflict of the 1920s.

During the 1930s, British policy became less strained. On July 6, 1934, Ali Fethi Okyar, close friend of M. Kemal, was appointed as the Turkish Ambassador to London, and in the same year Sir Percy Loraine was appointed as a new British Ambassador to Ankara. These

72Ömer Kürkçüoğlu, "Turco-British Relations since 1920s" in William Hale and Ali İhsan Bağış (eds.), Four Centuries of Turco-British Relations, Humberside, Eothen, 1984, pp. 80-102. 
were significant points attesting to the shift in Anglo-Turkish relations from hostility to alliance.

A new step was taken with the signing of the Balkan Entente on February 9, 1934 under the leadership of Turkey and Greece, with the participation of Romania and Yugoslavia. The Entente was supported by both Britain and France. It was obvious that the expansionist policies of Italy and Germany were affecting the British and Turkish interests in the region. Turkey also took the lead in the conclusion of the Sadabad Pact in July 1937 with Iran, Iraq and Afghanistan, which created a new chain of indirect co-operation between Britain and Turkey since Britain was involved as the mandatory power in Iraq. The Italian attack on Ethiopia in 1935 caused similar concern in both countries.

German occupation of Czechoslovakia on March 15, 1939 led Britain to take counter-measures. As a result Britain and France offered to protect Greece, Romania and Turkey against German attack. However, Turkey proposed that this collaboration should take the form of an alliance. The meeting between Britain, France and Turkey ended with the Turco-British and Turco-French declarations of May 12, 1939 and June 23, 1939 respectively. Finally the TurcoBritish-French Pact was signed on October 19, 1939.

During the war, Britain and Russia pressured Turkey to participate in the war on the Allied side. Turkey's involvement in the First World War, however, had produced tragic consequences and there was an understandable reluctance to enter the second conflict. Thus Turkey's official reply was that its army and air force lacked equipment to perform the tasks, which were demanded of them. Thus, after resisting to the end of the War, Turkey finally declared war on Germany on February 23, 1945. Turkey's decision was essentially aimed fulfilling the pledge taken at the Yalta conference that is to qualify for the founding membership of the United Nations. The confrontation with Britain during the war over Turkish neutrality, however, led to a cool atmosphere afterwards.

Later on, Britain encouraged Turkey to lead the establishment of the Baghdad Pact in 1955. The Pact was reorganised in 1959, after the revolution in Iraq and her withdrawal from the pact, as the Central Treaty Organisation (CENTO). Both Britain and Turkey agreed for the continuation of the Pact under the new framework. 
Cyprus became the main issue between Britain and Turkey in the second half of the 1950s. Finally, Britain, Greece and Turkey as well as the Turkish and Greek Cypriots themselves reached a consensus in 1959/60 on the basis of the Treaty of Guarantee and the Cyprus Constitution of 1960.

\section{The Straits}

The British Government supported the Turkish proposition for the revision of the regime of the Straits through the Montreux Convention in 1936. After Stalin's claims over the Turkish territory and requests for the revision of the status of the Straits in 1945, Britain supported Turkey with the US against Russian advances. ${ }^{73}$

\section{The Nature of the Regime and Economic Issues}

King Edward's visit to İstanbul in 1936, had facilitated a rapprochement between the two sides. Another factor, which brought about a closer relations between Britain and Turkey was the credit arrangements signed in London in 1938. In the post-war world, the Russian demands pushed Turkey into the Western camp in the emerging Cold War conflict. This alignment was sealed by her admission to NATO together with Greece in 1952. Britain's relations with Turkey thus became part of the multilateral structure of the western alliance. ${ }^{74}$

The British Ambassador Sir B. Burrows presented an accurate and full account of all the important and dramatic developments in Turkey during 1958, which influenced Anglo-Turkish relations. In his annual report to the Foreign Secretary he described the year as starting badly for Cyprus. ${ }^{75}$ Basically, the sides had different proposals to solve the Cyprus problem. Britain's main aim was to

\footnotetext{
${ }^{73}$ Osman Okyar, "Turco-British Relations in The Inter-War Period: Fethi Okyar's Mission to London" in Hale/Bağış, ibid., pp. 62-79.

${ }^{74}$ William Hale, "Introduction: The Historical Background" in ibid., pp. 1-9.

75FO-371/144739, RK 1011/1, Burrows to FO (Selweyn Lloyd), Ankara, 17 February 1959.
} 
preserve the British bases and keep her influence over the Cyprus Government. Turkey's proposal was partition (Taksim) of the Island between Turkish and Greek sides. There were many anti-British demonstrations held in Turkey because of the Cyprus question.

In 1959, especially after the London agreement concerning Cyprus on February 19, Anglo-Turkish relations moved to a new phase. This good relationship reflected in the economic and cultural areas as well as in politics. The British Ambassador encouraged the Foreign Office (FO) to increase the scale of British institutions in Turkey, such as opening new British Council branches, supporting Turkish universities and colleges with equipment and staff from Britain. Moreover, he pointed out that, British credit and economic and military aid should be increased and British investment should be encouraged by the government. ${ }^{76}$ Furthermore he argued, that because conditions for trade and business in Turkey were favourable, these activities would improve British influence in Turkey, thus enabling Britain to deal with Turkey on difficult issues such as Cyprus and the Middle East from a position of some strength. Important too, he pointed out, were strategic facilities as the rights of overflying, which the British enjoyed in 1959.

The Ambassador pointed out that even though British assistance to Turkey had been received with appreciation, it was small when compared with that of the US and Germany. He emphasised that Britain could, or should, compete with these countries in providing financial and economic assistance. But the assistance to the Turkish armed forces was probably the most spectacular evidence of what the Ambassador called British friendship. According to his view, the Turks evidently attached particular importance to the relationship in naval matters. For all these reasons, he recommended that Britain should transfer a mine-layer ship to Turkey on the basis of a loan from NATO, but he also raised the problem of how the Turkish Government would be able to meet the cost of $£ 500.000$ for the necessary refit. ${ }^{77}$ The attitude of the FO was different from that of the Ambassador's recommendation, as the following reply shows: "We have already done a good deal for Turkey in the past year, in

\footnotetext{
76FO-371/153030, RK 1011/1, Burrows to FO (Selweyn Lloyd), Ankara, 26 January 1960.

${ }^{77}$ FO-371/144780, Burrows to FO, Ankara, 11 April 1959.
} 
particular by our contribution of $£ 3.5$ million to the O.E.E.C credit and since last August at any rate our relation with the Turks have been close and cordial and not in need of any artificial stimulus". ${ }^{78}$

The point of seeking to develop good relations, however was accepted. The Turkish Minister of Construction was invited to Britain by the British Government for a few days' visit. That invitation had been strongly recommended by the Ambassador in Ankara, because of the Minister's close relations with Prime Minister Menderes and because there had been no official visit from Turkey at ministerial level since 1956. The Ambassador mentioned that it would be a good opportunity to reaffirm good political relations between the allied countries after the Cyprus confrontation. The minute written by the assistant under-secretary Ross expressed agreement, "I entirely agree with Sir. B. Burrows' suggestion. It may annoy the Greeks but that need not deter us from inviting M. Berk". ${ }^{79}$ The British FO had traditionally tried to balance their relations with both Turkey and Greece especially over Cyprus. However, on this occasion, it decided in favour of Turkey, and the Minister of Construction paid his visit to the UK between March 30-April 4, 1959.

The relationship was emphasised further by the visit of the British Defence Minister Duncan Sandys to Turkey from 19 to 25 May $1959 .{ }^{80} \mathrm{He}$ attended a military exercise in the east and south of Turkey. The visit was successful for it showed Anglo-Turkish cooperation against the Soviets and against Iraq's new revolutionary government.

Then, the Commander-in-Chief of the Middle East Air Force (located in Cyprus) of the UK paid a courtesy visit at the beginning of April. Both the Ambassador in Ankara and the FO agreed that the visit was valuable for strengthening British relations with the Turkish Air Force. ${ }^{81}$ The British Foreign Secretary Selwyn Lloyd saw the Turkish Ambassador M. N. Birgi on July 9,1959. They exchanged views on recent political developments over the world and the Anglo-

\footnotetext{
${ }^{78}$ FO-371174778, FO to Ankara, 25 March 1959.

${ }^{79}$ FO-371/144753, The note written by A. D. M. Ross ,14 January 1959.

${ }^{80}$ FO-371/144754, Burrows to FO, Ankara, 4 January 1959.

${ }^{81}$ FO-371/144785, Burrows to FO, Ankara, 10 February 1959 and FO to Ankara, 24 February 1959.
} 
Turkish relations especially concerning the Cyprus issue. The Secretary told the Ambassador that they were worried about the difficulties, which the Greeks were making over the detailed working out of the London agreements. At the London Conference, Averoff had taken the line that the British must have what they needed. Birgi replied that it was in the nature of Greeks to haggle and that he did not think that their recent manoeuvres should be taken too seriously. ${ }^{82}$

Sir Winston Churchill visited Turkey on 5 August 1959; Prime Minister Menderes and Foreign Minister Zorlu met him. According to the British Ambassador, the visit was counted as a considerable success from every point of view. ${ }^{83}$ There were a whole series of British goodwill missions sent to Turkey after the London agreement in 1959 .

A crucial question for the British government in 1959 was whether the Menderes administration would continue to provide political stability in Turkey. The reports from the Embassy, though providing evidence of some internal problems in Turkey in 1958 and 1959 , advised that the situation was under the control of the government. Consequently, the possibility of military action against the government seemed to be very unlikely. ${ }^{84}$ Their view changed dramatically in April 1960. Burrows pointed out in his despatch dated April 22,1960 that there was a potentially revolutionary situation. ${ }^{85}$ He emphasised that the circumstances in which he could foresee military intervention designed to protect the Constitution in the event that Menderes decided to suspend the Constitution and carry on governing by decree. ${ }^{86}$

The British FO was now concerned about the internal security of Turkey as the Foreign Secretary would be participating in the

${ }^{82}$ FO-371/144752, RK 1051/5, FO (Selweyn Lloyd) to Burrows, 13 June 1959 (Record of Conversation).

${ }^{83}$ FO-371/144793, Burrows to FO, Ankara, 8 August 1959.

${ }^{84}$ FO-371/144739, RK 1010/1, Burrows to FO (Selweyn Lloyd), Ankara, 17 February 1959.

85FO-371/153032, RK 1015/10, Burrows to (Selweyn Lloyd), Ankara, 22 April 1960.

${ }^{86}$ FO-371/153032, RK 1015/8, The Note written by G. M. Galbraith (Southern Department), 20.4.1960. 
NATO ministerial meeting in İstanbul in early May. They realised that certain senior officers were already showing discontent at the government's measures against the opposition. In his telegram, Burrows considered, but appeared to discount the likelihood of early violence. E. J. Barnes, the Assistant head of the Southern Department, minuted: "I am sure we can rely on Burrows to wam us in time of any likely threat to security". 87

As can be seen, the British diplomats were following Turkish internal and the foreign policy closely. They had close relations with the government, but they were also trying to establish contact with the opposition party and its leader İnönü.

\section{The British Attitude towards the Coup}

The American State Department told reporters on May 27, 1960 that the overthrow of the Menderes regime came as a complete surprise to Washington. ${ }^{88}$ The US State Department was not sufficiently informed by the American Ambassador in Ankara. Fletcher Warren mentioned in his reports that Menderes was very strong, the army supported him and the Chief of General Staff, General Erdelhun, obeyed the Prime Minister. According to Metin Toker, a distinguished journalist and son-in-law to İnönü, the US Ambassador was nicknamed "the tall idiot" among the intellectual community in Ankara. He was almost two metres tall and they described him as an "idiot" because of his misleading information to his government about Turkey. ${ }^{89}$

On the other hand, the British FO was not as surprised by the coup in Turkey as the US, since the British Embassy in Ankara was sending information regularly concerning the internal situation in Turkey. In a long despatch in which he detailed how the internal scene in Turkey had been characterised by periodic outbursts of violence and bitterness with a quieter period in between 1955 and

${ }^{87}$ FO-371/153032, RK 1015/8, Note by E. J. Barnes (Southern Dept.), 20.4.1960.

${ }^{88}$ Weiker, The Turkish Revolution, p. 160.

${ }^{89}$ Metin Toker, Demokrasinin Ismet Paşa'lı Yılları, Inönü'nün Son Başbakanlığı, 1961-1965, Ankara, Bilgi, 1992, p. 48. 
1960, the British Ambassador also pointed out the mistakes made by the Menderes administration in dealing with the opposition and in particular the trend towards repressive action against the opposition and the press. This trend of DP thinking has sometimes been rationalised into the belief that Turkey is not suited to the forms of democracy practised in the West and would loose its own individuality if it tried to adopt them. There is some reason to believe that the Prime Minister has been attracted by this philosophy, though he had in the past been shy of taking the measures needed to put it into effect. 90

Although only in Ankara for six months, the Ambassador had gained an accurate understanding of Turkish politics, which was evidence of the good support he received from the Embassy Staff. He pointed out the possibility of a potentially "revolutionary situation" a month earlier in one of his despatches. This was particularly evident in his despatch dated April 22, 1960, which was prepared after the establishment of the "Investigation Commission".

The Commission has already banned all party political activities and meetings in the country. Future developments are uncertain. There is a potentially revolutionary situation. But İnönü and his party do not at present seem to want to push matters to extremity. Indeed in his second speech in the Mejlis debate on April 18, he specifically argued against any such tendency. The Government on their side may also be inhibited from going to extremes by a lack of internal unity, uncertain about the army, and, for the immediate future, the prospect of a Nato Ministerial Meeting in Istanbul at the beginning of the next month. 91

The British FO spokesman in London had no comment to make on aspects of the coup, which was described as an internal affair for Turkey. ${ }^{92}$ He said that no reports of any damage suffered by British subjects or property during the coup. He added that there were about 3500 people in Turkey who were either British subjects or Britishprotected persons.

90FO-371/153032, RK 1015/10, Burrows to FO (Selweyn Lloyd), Ankara, 22 April 1960.

${ }^{91}$ Ibid.

${ }^{92}$ The Times, 28 May 1960. 
Burrows had close relations with the American Ambassador in Ankara. Fletcher saw General Gürsel just a day after the coup at an informal level. The new Foreign Minister of Turkey, Selim Sarper, told Burrows that General Gürsel would also be glad to see other Ambassadors if the British side wished, but he had not felt it right to invite the British Ambassador formally. In the circumstances the Ambassador sought urgent instructions from the $\mathrm{FO}$ as to whether he should see General Gürsel in advance of the completion of the recognition the new government. The FO authorised this and agreed with the view of the Ambassador, concerning the importance of establishing early contact with the new Turkish regime and the fact that the American Ambassador had already called on the General. So the British ambassador should seck a private interview with the latter as soon as practicable. ${ }^{93}$

According to FO information about the US attitude towards the new Turkish administration, the US State Department regarded a communication made to them on the previous day by the Turkish Ambassador in Washington as sufficient evidence to justify them the recognition of the new Turkish government without more ado. Accordingly, the US Ambassador in Ankara had received instructions from Washington to resume the ordinary conduct of business with the new Turkish government on May $30 .{ }^{94}$

By this time, the British was very anxious to recognise the new Turkish government simultaneously with the US, and did not wish to appear to be lagging behind. ${ }^{95}$ The Canadian, Pakistani and Indian Ambassadors in Ankara were also keeping in close touch with the British Ambassador and did not anticipate any long delay on the part of their governments. Thus, the British government recognised the new Turkish government on May 30:

Her Majesty's Government in the United Kingdom fully share and reciprocate the wish of the Turkish Government for the maintenance of the relations of friendship and alliance which so happily exist between the two countries.

${ }^{93} \mathrm{FO}-371 / 153046$, RK 1051/3, Burrows to FO, Ankara, 29 May 1960.

${ }^{94} \mathrm{FO}-371 / 153046$; RK 1051/2, FO to Washington, 29 May 1960 and FO371/153046, RK 1051/3(B), Burrows to FO, Ankara, 29 May 1960.

95FO-371/153046, RK 1051/3, FO to Ankara, 29 May 1960. 
Her Majesty's Embassy avails itself of this opportunity to renew to the Ministry of Foreign Affairs the assurances of its highest consideration ${ }^{96}$.

The Commonwealth countries were informed about this situation through the Commonwealth Relations Office with a telegram dated May 30. As the British recognised the new government without prior consultation with their NATO and CENTO allies, the FO sent instructions to Burrows to point out on a personal basis that they were in a special position because of the Cyprus negotiations. It was essential that they should be able to transact business on this subject with minimum delay. 97

The FO then sent comprehensive instructions to the Ambassador in Ankara, concerning his meeting with General Gürsel. It was mentioned that Britain, of course, had no intention of interfering in Turkish internal affairs and realised that it would be quite improper for her to do so. Nevertheless, throughout the anxieties of the Suez affair, the early days of the Baghdad Pact, the revolution in Iraq and the Cyprus crises, Menderes, later supported by Zorlu, acted as a true friend, an ally and a worthy spokesman of the Turkish nation in support of their alliance with Britain. The British therefore thought that at this time of political adversity, this would be remembered in their favour and influence the new government in their treatment of Turkey's former leaders. They also mentioned that they did not want this to be a formal démarche but the indication of a proper interest in the fate of old friends and colleagues, without in the least condoning their handling of Turkish internal affairs. ${ }^{98}$

According to his despatch, the Ambassador expressed his government's attitude towards the new Turkish government, during his conversation with General Gürscl on May 31. He said that it would be quite wrong for them to comment on the internal situation of another country, but Turkey was a friend and ally, and they were naturally sad when she was in trouble. They liked to see Turkey healthy and strong. He then outlined the points of contact which they

96FO-371/153046, RK 1051/3, FO to Ankara, 30 May 1960.

${ }^{97}$ FO-371/153046, RK 1051/2, C. R. O. to Commonwealth Countries, 30 May 1960.

98FO-371/153046, RK 1015/29, FO to Ankara, 29 May 1960. 
had with Turkey: NATO, CENTO, Cyprus, cultural activities, contributions to Turkish economic development and their help over the provision of equipment of the armed forces. These were all a reflection of the common outlook on world problems, which they shared with Turkey. ${ }^{99}$ In another despatch, Burrows also pointed out that he had, of course, made the usual remarks that it was inappropriate for him to comment on the internal situation etc. when he met with Foreign Minister Sarper on June 21, 1960.100

The Ambassador emphasised that he had been particularly glad to know from the statements of the new government that her foreign policy was basically unchanged. General Gürsel mentioned, in his appreciation, the many points of contact and common interests that they had and expressed the wish that their relationship would grow ever more close and that there should never be a cloud over it. At the same time they spoke about the former politicians. The Ambassador said that he needed assurance about their health and security. The Ambassador had known his Foreign Minister had personal interest in the fate of the former ministers. General Gürsel said that it was very natural that the British authorities should have these feelings of humanity towards people with whom they had had such close collaboration and that he fully appreciated their feelings on the subject. He wished to emphasise that he himself had no feelings of personal hostility towards them. He said he had acted because of what he saw as his duty, not because he wanted to act against particular individuals. ${ }^{101}$ Later the British plea concerning the members of the previous government was repeated to the Turkish side again through the Ambassador in a non-aggressive manner. ${ }^{102}$

Sarper was under-secretary of the Turkish Ministry of Foreign Affairs before he was appointed Foreign Minister by the military junta on May 28, 1960. The British under-secretary of state, Sir F. H. Miller sent a friendly message to Sarper in which he mentioned that it was not for him to comment on the internal affairs of Turkey. He was, however, delighted that an old friend and trusted colleague should

${ }^{99} \mathrm{FO}-371 / 153046$, RK 1051/5(A), Burrows to FO, Ankara, 30 May 1960. ${ }^{100} \mathrm{FO}-371 / 153035$, RK 1015/40, Burrows to FO (A. D. M. Ross), Ankara, 21 June 1960.

101 FO-371/153046, RK 1051/5(A), Burrows to FO, Ankara, 30 May 1960.

${ }^{102} \mathrm{FO}-371 / 153035$, FO (Ross) to Burrows, 29 June 1960. 
occupy the post of Foreign Ministry in the new government. He also mentioned that ever since they first met at the UN in 1951, he had had a high respect and feeling of warm friendship for him. He sent Sarper his very sincere good wishes looking forward to the same close cooperation with him as he had had with Sarper's predecessors. He left the initiative to the Ambassador when and on what terms to deliver that message. Miller also informed the Ambassador that if he felt that the new government was firmly in the saddle, he would like his message to Sarper to be one of the earliest messages he was to receive. ${ }^{103}$

The Ambassador met Sarper for the first time as the Turkish Foreign Minister on May 31. Sarper explained to Burrows that the programme and the orientation of the foreign policy of the new government and the general intentions of the military authorities, including General Gürsel. Finally, Sarper remarked that part of what he said to the Ambassador represented "the secrets of the new government". The Ambassador then recommended to the FO not to hint at any proposal until it was made public in Turkey. ${ }^{104}$

It can be observed from this despatch that the British wished to avoid any appearance of intervening into Turkish domestic politics, and they called the coup as an internal affair of Turkey. However, they also reminded the military government of their close relations with the former government members. This was explained as the former Prime Minister Menderes and Foreign Minister Zorlu had close relations with their British counterparts.

In June 1960, the FO sent an important message to Burrows concerning Turkey's internal and foreign relations. It shows that he could not avoid being drawn into conversation with Sarper, which was indeed valuable to the British, since the likely development of the Turkish internal situation was naturally a matter of interest to them. On the other hand, the Permanent Assistant Undersecretary of the State, A. D. M. Ross, wrote that, "they could not really expect them to abandon everything to the whim of the ballot box and it may not be a bad thing for them and for Turkey's other allies". He also added that Turkey should be ruled by a firm hand, determined to stop the rake's

${ }^{103}$ FO-371/153054, RK 1051/4, FO to Ankara, 28 May 1960.

${ }^{104}$ O-371/153046, RK 1051/8, Burrows to FO, Ankara, 31 May 1960. 
progress of recent expenditure, to check corruption in high places and generally to return to the spirit of Atatürk. ${ }^{105}$

One can easily see that British policy makers were not particularly interested in the Turkish democratic process. They really concentrated on British interests in the political, economic and military spheres. The impact of the coup on Turkey's foreign relations was remarkably small. 106 When the coup occurred, British politicians were pleased about the lack of major change in Turkish foreign policy. When they saw the first public announcement of the new government reiterating Turkey's alliance with NATO and CENTO, and its allegiance to other existing international settlements, including Cyprus, they realised that there were advantages for Britain especially in the case of Cyprus. ${ }^{107}$

During his meeting with Sarper on June 21, the British Ambassador especially wanted to know the election date and whether the Democrats would participate in the next election. He also wished to learn about the future of the members of the previous government. Sarper mentioned that the trial of the members of the previous government would be entirely impartial and free from political pressure. The Ambassador did not believe his explanation and reported that "Sarper's remarks about the trials are even less probably correct than I thought at the time." He argued that the provision about death sentences being carried out by the NUC, for instance, seemed to make it clear that the whole process would be completed while they were still there. They had also heard from a source close to the NUC that they intended to complete the trials before handing over power. 108

${ }^{105} \mathrm{FO}$ (A.D.M Ross) to Burrows, 29 June 1960, FO-371/153035.

${ }^{106} \mathrm{FO}-371 / 160212$, RK $1011 / 1$, Burrows to FO (The Earl of Home), Ankara, 6 January 1961.

${ }^{107}$ The Manchester Guardian, 28 May 1960.

${ }^{108} \mathrm{FO}-371 / 153035$, RK 1015/40, Burrows to FO (Ross), Ankara, 21 June 1960. 


\section{The British Attitude towards the Trial and the Treatment of the Fallen Regime}

The trial of the former members of the DP government and MPs opened on October 14, 1960, four and half months after the coup, on the island of Yassiada on the Sea of Marmara. The trial lasted almost eleven months until September 15, 1961. The defendants included former President Celal Bayar, former Prime Minister Adnan Menderes and former speaker of the Parliament Refik Koraltan, the entire cabinet, all DP deputies, several former provincial governors, the former Chief of General Staff, local officials and police officers involved in cases of restricting freedom of movement and the shooting at the universities, and a number of businessmen involved in corruption cases. Most had been confined to the Island from early June 1960.

The pre-trial investigations were carried out by a special High Investigation Commission of thirty-one members selected by the military regime. The trial was delayed for more than four months while the Commission carried out its work. ${ }^{109}$ There was a team of prosecutors headed by Ömer Altay Egesel and the tribunal of nine judges, selected by the NUC. There were 202 sessions of the trial, almost 150.000 spectators and 592 defendants during the elevenmonth period. At the end of the sessions the verdicts were announced by the judges on September 15, 1961. There were 15 death sentences, four of them accepted by unanimous vote and eleven by majority. 418 defendants were jailed between 6 months and 20 years, 123 defendants were acquitted, and 5 defendants had their charges dismissed. ${ }^{110}$

According to the Constitution, the death penalties had to be confirmed by the NUC. It cannot be said that the trials were free from interference by the authorities. The judges and the prosecutors were directly appointed by the government that was formed by the military Committee. The British Ambassador to Ankara pointed out that the reasons for instituting the trials were varied. Most important was

\footnotetext{
${ }^{109}$ Weiker, The Turkish Revolution, p. 27.

${ }^{110}$ Hikmet Özdemir, Türkiye Cumhuriyeti, İstanbul, Iz, 1995, p. 228.
} 
probably the wish to justify the coup. The ambassador commented, "the Turks are legalistic people".111

This analysis was accurate because the law lecturers from İstanbul University, including the Rector, Professor Onar, advised the NUC to legalise the coup. When the coup occurred, the officers intended to hold new elections and then transfer the authority to the civilian government in not more than three months. The academics encouraged the coup leaders to try the former government ministers and members of the DP before the new elections were held, pointing out that if they were not convicted and found guilty they would be entitled for re-election and could then form the government again. The advice of the intellectuals to follow a proper legal process delayed the outcome for almost eleven months. The officers seem to have thought that the previous government members could be more speedily disposed of as a result of a short trial. The length of the trials without verdict led to the postponement of the elections and the postponement of the return to civilian regime.

It can be argued that some of the intellectuals supported the coup in Turkey directly and that their advice led to a simple coup turning into a "revolution". 112 The NUC abolished the existing constitution and ordered the preparation of a new constitution by a commission. As they realised that they were guilty according to the previous constitution, they changed it and claimed that the army had done nothing other than fulfil its patriotic duty according to both the previous and present Constitutions. ${ }^{113}$ Thus, they tried to legalised the coup.

There was a contrast between the military government's first public announcement that "their movement was not for or against any person or class" and the holding of the Yassiada Trials. The only accused were from the former government party members and their supporters. This meant the coup was certainly against the DP. The head of the military government, General Gürsel, however, emphasised that there would not be any execution of former ministers.

${ }^{111} \mathrm{FO}-371 / 160212$, RK $1011 / 1$, Burrows to FO (The Earl of Home), Ankara, 6 January 1961.

${ }_{112}$ Birand/Dündar/Çaplı, Demirkırat, p. 215.

${ }^{113}$ Hikmet Özdemir, Rejim ve Asker, İstanbul, Afa, 1989, pp. 217-219. 
The British government, too, was concerned about the situation in Turkey. Soon after the beginning of the trial sessions, the Ambassador sent regular despatches about the trials and the possible verdicts, especially those affecting the previous Prime Minister and the other ministers. The Turkish Foreign Minister Sarper met the foreign representatives in Ankara on November 25, 1960 and advised them how best to handle the situation, taking Turkish susceptibilities into account. R. F. G. Sarell, who was then the Head of Southern Department in the British FO, summarised Sarper's advises to his government in a note; "To make no representations about death sentences since these would only annoy and embarrass General Gürsel who had himself expressed strong opposition to any executions". Reportedly, he had told Sarper that he had already decided to resign if any death sentences were carried out, adding that he could go no further than this.

Sarper estimated that there was one in two chance no death sentences would be promulgated, and a 80/20 chance against execution in the event of promulgation. ${ }^{114}$

Burrows also reported on these developments, and on the same document there was a minute written by an officer in the FO: "Very interesting. I am sure we should follow Sarper's advice. The Prime Minister might be interested to see this".

The FO then sent a despatch to the Prime Minister and emphasised that; "It seems as though things are going the way we want at the moment. The feeling in the Department is that we must certainly follow Sarper's advice". ${ }^{115}$ In November 1960, Prime Minister Macmillan agreed to send a personal message to General Gürsel concerning the Yassiada Trial to be delivered by the Ambassador in Ankara.

The Ambassador was given the discretion to make any changes and the initiative to decide when and how to deliver it to Gürsel. In the event, Burrows waited for nine months before handing over the

${ }^{114}$ FO-371/153038, RK 1018/1/83, Burrows to FO, Ankara, 26 November 1960.

115PREM-11/4552, FO to Prime Minister, 30 November 1960. 
message on August 4,1961 as the trial was near to its end with unfavourable verdicts likely. The following were the main points in the message:

This is a matter of Turkish internal law and it is not for us to comment on the course of the trials or the verdicts. The Prime Minister would only like to draw General Gürsel's attention to the effect which executions are likely to have in the United Kingdom. We attach great importance to our friendship and alliance with Turkey. Menderes and his colleagues were known as staunch upholders of Turkey's Western connection and NATO and CENTO. They played a large part in the Cyprus settlement. The exccutions of these men would be regarded in the United Kingdom as inconsistent with the high ideals of the Western community to which Turkey and the United Kingdom. ${ }^{116}$

He reported that the message had received wide circulation among the key military personnel. The FO commented optimistically that the message had created a considerable impression. ${ }^{117}$

Burrows had been advised by the FO not to intervene earlier and wait to the last possible moment to avoid the danger of doing more harm than good by accusations in Turkey of foreign interference. ${ }^{118} \mathrm{He}$ was advised, according to the despatch, in any event to guard against this danger, and emphasise the would be effect of possible sentences of undue severity on Turkey's friends in the Western world. This position seemed to be in line with the general opinion of foreign representatives at Ankara and with that of other governments, including the US with whom the British had been in touch. Burrows had been asked to keep in touch with his principal allied colleagues, and FO had suggested that the Iranian Ambassador to Ankara should also keep in close touch with Burrows. ${ }^{119}$

Even before the actual transmission of the message from Macmillan, the British government expressed its feeling to the Turkish authorities at every possible opportunity. In December 1960, Selwyn Lloyd, previously the Foreign Secretary and now the British

\footnotetext{
116FO-371/160214, RT 1016/49, Burrows to FO, Ankara, 3 March 1961.

${ }^{117}$ FO-371/160791, Minute by E. E. Tomkins from Central Department, 8 September 1961.

${ }^{118}$ FO-371/153038, RK 1016/18, FO to Tehran, 25 November 1960.

${ }^{119}$ FO-371/153038, RK 1016/18, FO to Tehran, 15 November 1960.
} 
Chancellor of the Exchequer, met the Turkish Foreign Minister Sarper, during OECD meeting. Lloyd asked Sarper about the trial. Sarper said that the defendants were being given full facilities and a fair trial. Lloyd also asked about the result of the trials. Sarper mentioned that a powerful section within the junta which included General Gürsel, was against promulgation of any death penalty. The Chancellor of Exchequer said that he was relieved to hear that, and he thought it would be a tragedy for Turkey if there were any executions. $\mathrm{He}$ also emphasised that those on trial had been good friends to the West. Sarper said that he completely agreed and thought that he could reassure the British Minister that there would not be any death sentences actually carried out. ${ }^{120}$

While, the British Ambassador kept close relations with the mission of the allied countries in Ankara concerning possible death sentences at the end of the trials, the FO also kept contact with the allied missions in London. The German Ambassador met the permanent Under Secretary of State, Hoyar Miller, on November 7, 1960. They agreed that any premature intervention would be a mistake and that any representations should be held up until the moment when they were likely to prove most effective. Miller took the opportunity of adding that the British believed at one time that the German government had thought of linking this question with that of their economic relations with Turkey. He also thought that it would be a mistake to link the two matters, and that pressure of this kind on the Turks might be self-defeating. The German Ambassador said that he understood this and gave the impression that the German authorities had now dropped the idea. ${ }^{121}$

Fletcher Warren, then American Ambassador to Ankara, told Burrows that in the very early days of the coup, he had told Gürsel that executions would have a bad effect on American opinion and would thus make it more difficult for the US government to obtain Congressional approval for aid to Turkey. Burrows mentioned that the Germans and the French might also try to influence the Turks in this matter through the Common Market discussion. He pointed out that he thought it was a great mistake to try to introduce this economic leverage on Ankara. In fact, he doubted if the American Ambassador

${ }^{120}$ FO-371/153036, RK 1015/71, FO to Ankara, 16 December 1960.

${ }^{121}$ FO-371/153037, RK 1016/11, FO (Sarell) to Burrows, 7 November 1960. 
was wise to do so, adding, "The Turks are oriental enough to enjoy standing on their honour against sordid economic considerations. An appeal to their prestige as a civilised nation is more likely to succeed". 122

The Turkish Government had earlier issued invitations to the head of Foreign Missions to attend the trials. The FO sent a despatch to Ankara concerning this situation, which emphasised that the Ambassador should co-ordinate friendly allied missions, in particular with his US colleague;

Subject to such co-ordination, I should not consider it appropriate for Your Excellency to attend in person but I should see no objection, and, indeed, some advantage if you were to be represented by a member of his staff as an observer. Such attendance would avoid any discourtesy to the present Turkish authorities and would enable him to form an accurate assessment of the proceedings without implying any approval of the trials or of their outcome. ${ }^{123}$

This message shows the dilemma of the British government who wished to continue good relations with the existing Turkish government whilst avoiding approval of the military coup and approval of the kind of special trial instituted to arraign members of a previous government. They calculated that the militarily controlled government would be likely to stay in power for some time. For strategic and economic reasons, membership of CENTO and NATO, and in consideration of the Cyprus question, they would continue to deal with the existing Turkish rulers. The policy is understandable if British interests are considered, but from the humanitarian or moral point of view, the British government compromised. It nevertheless should be noted that they tried to stop the executions. In the same despatch, the FO instructed Burrows on how to react if death sentences were passed.

Burrows mentioned that he had received a very strong hint from the Turkish Foreign Minister on March 3, 1961. Sarper emphasised that it would be most useful if the Queen said something personally to

122FO-371/153037, RK 1018/1, Burrows to FO (Ross), Ankara, 21 October 1960.

${ }^{123} \mathrm{FO}-371 / 153037$, RK $1016 / 11$, FO (For the Secretary of State) to Burrows, 10 October 1960. 
Gürsel when they met in Ankara on March 6 about the bad impression that would be caused abroad if there were executions resulting from the Yassiada trial of the former president, prime minister, etc. Burrows said that he thought it would be most unusual for Her Majesty to speak on a matter of this kind, but that he would send to Miller a personal message on this subject. Sarper underlined the vital importance to him that it should not be known that he had made any such suggestion. 124

Sarper was one of the prominent diplomats during the DP government. He was appointed as foreign minister by the military regime soon after the coup. He had wide experience on international community and foreign relations. He was personally against death sentences, and he was aware of the negative effect on Turkey's reputation they would have in the international arena. He had also close relations with Burrows and Miller. Thus Sarper might well have believed that it would be possible to work with the British to prevent this end.

During the stop of Her Majesty's aircraft at Ankara airport on its way from Tehran to London, the Queen had a short conversation with General Gürsel at the Airport lounge. His Royal Highness the Duke of Edinburg, the Earl of Home and Selim Sarper were present. When they asked Gürsel about the political situation in Turkey, he mentioned that his plans were moving in the right direction. $\mathrm{He}$ also said that:

There could be no intervention while the due process of the law was being carried through. The lawyers for the defence were good and the judges were the best in Turkey. The matter must be left to their consciences. But the verdict was subject to review by himself and the NUC It would be then that he would have the opportunity to intervene on the side of clemency, should that be necessary and right. ${ }^{125}$

He could not, of course, anticipate the result of the trial, but would say that his government had carried out a bloodless revolution, and bloodless they wished to keep it. Prince Philip suggested that a decision to show clemency would certainly be welcomed by all

${ }^{124}$ FO-371/160214, CT 1016/49, Burrows to FO (H. Miller, personal), Ankara, 3 March 1961.

125FO-371/160217, RK 1052/2G, FO to Burrows, 7 March 1961. 
Turkey's many friends overseas. ${ }^{126}$ This was the first official meeting that had ever taken place between a Turkish and British Head of States. King Edward VIII met Kemal Atatürk privately in İstanbul in 1936, but certainly no British monarch had visited "Turkey's still austere capital of Ankara". The Queen was also the first foreign head of state to visit Turkey since the military coup d'état. ${ }^{127}$

As mentioned earlier, the FO had sent a message to Burrows from Prime Minister Macmillan to General Gürsel in November 1960, which he was authorised to deliver at any time. He thought it appropriate in support of representations about the undesirability of executions. ${ }^{128}$ On August 4, 1961, on the last day of the trials, Burrows delivered the message of his Prime Minister to Sarper for Gürsel. The final verdicts were pronounced in the middle of September. The message was the second written message that Sarper received from a head of state. The first was from the German Chancellor Adenauer. Sarper told the Ambassador that the German message approached the matter from a slightly different point of view from the British, but he gave the impression that he regarded it as effective and potentially useful. ${ }^{129}$ During the meeting Sarper explained to Burrows the internal situation of the NUC and what was likely to happen. He pointed out that there was another group organised in the army which described itself as the real representative of the army, known as the Armed Forces Union (AFU). Sarper mention that they were likely to shadow Committee and they wanted some executions carried out. Sarper wanted help from abroad to encourage the members of the NUC, who were still against the executions. ${ }^{130}$

On 15 September, the judges delivered their verdicts. There were 15 death sentences, four of them were accepted unanimously and the rest by majority vote. By a majority of fourteen to eight, the NUC confirmed the death sentences in those cases where the Yassiada judges had reached unanimous verdicts. The eleven, who were

126 FO-371/160217, RK 1052/2G, FO to Burrows, 7 March 1961.

${ }^{127}$ The Times, 7 March 1961.

128 FO-371/160214, RT 1016/49, Burrows to FO, Ankara, 3 March 1961.

${ }^{129}$ FO-371/160791, CT 1016/17, Burrows to FO (The Earl of Home), Ankara, 5 August 1961. ${ }^{130}$ Ibid. 
sentenced by majority vote of the judges, had a life prison sentence confirmed by the NUC. The four, who were sentenced to death by unanimous vote were former-President Bayar, Prime Minister Menderes, Foreign Minister Zorlu and Finance Minister Polatkan. As Bayar was 78 year of age at the time of his sentence, he escaped execution because of his old age.

Death sentences were all pronounced under article 146 of the Turkish penal code, which prescribed capital penalties for "those attempting by force to change, replace or abrogate the Constitution of the Turkish Republic." The court held that this charge had been proved in spite of conflicting evidence by experts during the trials. ${ }^{131}$

The British FO sent a despatch when they saw the reports of death sentences and the statement that they would be carried out within 24 hours. They instructed Burrows, if he thought it would have any effect, to communicate the message. Burrows thereupon immediately delivered the message to Gürsel:

Your Excellency will no doubt recall the views about the state trials, which I ventured to express to you in my recent letter. These arguments seem to me particularly apt at the present time having regard to the interests of Anglo-Turkish friendship and of the western Alliance as a whole. I trust Your Excellency will appreciate the spirit in which I send you this further message. -Harold Macmillan. ${ }^{132}$

The former British Prime Minister Sir Winston Churchill also sent a similar message to Gürsel. ${ }^{133}$

As soon as they heard the verdicts of the trial, the US, British, German, French and Pakistani governments sent messages to Gürsel advising a postponement of the execution. Appeals for clemency poured into the NUC from İnönü, Türkeş, US President Kennedy, 134 Queen Elizabeth, Adenauer, De Gaulle and Ayub Khan who offered

\footnotetext{
${ }^{131}$ The Times, 15 September 1961.

132FO-371/160224, No:1921, FO to Burrows, 15 September 1961.

133 Ibid.

${ }^{134}$ Foreign Relations of the United States (FRUS), Volume XVI, 1961-1963, Washington 1994, p. 709.
} 
asylum to Menderes and Bayar if they were to sent to exile. ${ }^{135}$ They were all ignored by the NUC. Her Majesty's Government's, and other messages were too late to affect the NUC.

There were several reasons for this. First, the foreign missions in Ankara delivered their messages to Sarper rather than directly to Gürsel. Second, Gürsel had already lost his authority over the NUC. Third, the Chief of the General Staff Sunay already emphasised that failure to confirm the death sentences would create "discontent" in the army. ${ }^{136}$ Moreover, the messages, which were from abroad, were not read by the NUC members, but seemingly left on the table. Finally, the radical groups in the army were able to exert pressure over the NUC members. Although the generals in the Committee were against the executions, the junior members supported them.

Two ministers, former-foreign minister Zorlu and former finance minister Polatkan were hanged on September 15, 1961 on the island of Imrall. Menderes tried to commit suicide with sleeping pills. He was revived, but subsequently also hanged on September 17 in the same place.

The British media condemned the executions as harsh. The Sunday Telegraph pointed out that the marathon trial, which purported to carry the same weight as the Nuremberg tribunal, was a political slant, not an impartial legal process. ${ }^{137}$

It is important to ask the question why there were not internal reactions in Turkey against the verdicts and the carrying out of the executions. There were two important factors; first of all, martial law was in force and the strict security measures were in place. A ban on all public discussion about the trial on pain of severe penalties had been imposed by the military government. Any public demonstration for Menderes, even of grief, was dangerous. There was also censorship of the media. On August 21, two Turkish newspapers appeared with blank spaces on the front page, the result of last minute censorship by the martial law authorities. The news concerned the two party leaders, Osman Bölükbaşı, the leader of the Nation Party and

${ }^{135}$ The Daily Telegraph, 18 September 1961.

${ }^{136}$ Hale, Turkish Politics, p. 144.

${ }^{137}$ The Sunday Telegraph, 17 September 1961. 
Ekrem Alican, the Leader of New Turkey Party, statements of both had advocated openly that there should be no death sentences at Yassiada. ${ }^{138}$ The second factor, more controversially, was related to the character of the Turkish People. The British generally described the Turks as an "undemonstrative people". 139 This may be right, but at the time the Turkish public was not organised in such civilian institutions as labour or agricultural unions, media corporations or fully independent intellectual foundations such as universities and institutions of higher education. Thus, the general silence in the country did not reflect what individuals really felt.

\section{Concluding Remarks}

What then can be concluded from the in-depth examination of the period before the coup, the coup itself and the British reaction? The Menderes era was important and interesting for the improvement it introduced in multi-party democracy. When the DP took over power as a result of the election in 1950, it marked a new phase in Turkish democracy.

During the decade, more foreign economic and military aid and credit from the West, particularly from the US, was delivered to Turkey. They were used basically for the agrarian economy, technology and building roads. DP's economic policy was successful in the first five years, but in the second five, foreign countries suspended their credits and aid to Turkey because of the unplanned and uncoordinated economic policies of the DP government. The deterioration of the economic situation affected the political stability in the country. The opposition, the press, and the intellectuals increased their criticism upon the government. The government responded with censorship and other measures. In these circumstances, a group of military officers planned a coup against the government, seeing themselves as the guardians of the regime, a view that emerged from the history of the Turkish military-state tradition.

During the Menderes era, both the US and the UK were satisfied with the foreign policy of the DP government generally, and

${ }^{138}$ The Times, 22 August 1961.

${ }^{139}$ The Times, 19 September 1961. 
the policies it followed in the Balkans and the Middle East. During the establishment of the Balkan and Baghdad Pacts, Turkey played an important role. She also followed a steady course during the negotiations over the Cyprus issue. Thus, Britain had close relations with the DP government since the DP's policies confirmed with British interests. The DP also practised a strong anti-Soviet policy during the period, which gained favour from Britain and the US.

After the coup, British policy found itself in a dilemma. On the one hand the democratic process had been broken by an antidemocratic intervention. Britain could not have supported the kind of regime that emerged because of its commitment to democracy. On the other hand, British economic, strategic and military interests prompted it to continue its relations with the new military regime. In the event, it did not take the British government long to resolve the dilemma in consultation with the US. Thus, the British recognised the new Turkish regime just three days after the coup on May 30, 1960.

The military government established a special court for the members of the fallen regime. After the lengthy trials the verdicts were announced on September 15, 1961 and the military junta (NUC) confirmed four executions. Two former ministers and Prime Minister were hanged on 15 and 17 September 1961 respectively on the Island of İmralı.

The heads of foreign governments such as the US, Britain, Germany, France and Pakistan sent messages to Gürsel at the last moment to postpone the verdicts, but the NUC members ignored. Their manoeuvres were too late to protect even the lives of the ministers. It is also important to note that foreign governments, especially the British, were extremely reluctant to appear to involve themselves in Turkey's internal affairs. Although the British Government could have done more under the existing circumstances, their perceived immediate national interests took precedence. 